\title{
Oceanographic conditions over the continental shelf off Magdalena Bay (Mexico) in 2011-2012
}

\section{Condiciones oceanográficas en la plataforma continental frente a bahía Magdalena (México) en 2011-2012}

\author{
Oleg Zaitsev ${ }^{1 *}$, Armando Trasviña-Castro², Jean Linero-Cueto¹, Gilberto Gaxiola-Castro³, \\ Jushiro Cepeda-Morales ${ }^{3,4}$ \\ ${ }^{1}$ Centro Interdisciplinario de Ciencias Marinas (CICIMAR), Instituto Politécnico Nacional, Ave. IPN s/n, \\ Playa El Conchalito, CP 23096 La Paz, Baja California Sur, México. \\ 2 Centro de Investigación Científica y de Educación Superior de Ensenada (CICESE), Unidad La Paz, \\ 334 Miraflores, CP 23070 La Paz, Baja California Sur, México. \\ ${ }^{3}$ CICESE, Departamento de Oceanografía Biológica, Carretera Ensenada-Tijuana No. 3918, Zona Playitas, \\ CP 22860 Ensenada, Baja California, México. \\ ${ }^{4}$ Universidad Autónoma de Nayarit, Ciudad de la Cultura Amado Nervo s/n, CP 63155, Tepic, Nayarit, \\ México. \\ * Corresponding author. E-mail: ozaytsev@ipn.mx
}

\begin{abstract}
The hydrophysical results obtained during six oceanographic cruises in 2011 (February, April, July, and October) and 2012 (February and April) over a 50-station sampling grid in front of the Magdalena-Almejas lagoon system (Mexico) are presented. MODIS-Aqua sensor data $(1.1 \mathrm{~km})$ of sea surface temperature (SST) and chlorophyll $a$, and geostrophic current fields were analyzed during the sampling periods. In the northern part of the study area the pattern of the thermohaline structure shows subsurface intrusion of modified subarctic water, especially during February and April of both years. To the south, in July and October 2011, evident indications of subtropical subsurface water were found. The geostrophic current fields in February and April show a surface southward flow along the coast, which changes direction towards the North Pole in July and October. In spring, the satellite-derived SST showed negative anomalies of up to $4.5^{\circ} \mathrm{C}$ in the coastal zone, corresponding to cold upwelled water rising to the surface from a depth of 60-70 m. Based on the results, the study area can be considered the southern boundary of the transition zone between the subarctic and subtropical waters of the northeastern Pacific Ocean, with marked seasonality.
\end{abstract}

Key words: thermohaline structure, continental shelf, Baja California, California Current, Northeast Pacific Ocean.

RESUMEN. Se presentan los resultados hidrofísicos obtenidos durante seis cruceros oceanográficos realizados durante 2011 (febrero, abril, julio y octubre) y 2012 (febrero y abril) en una red de 50 estaciones frente al complejo lagunar Magdalena-Almejas (México). Se analizaron los datos de temperatura superficial del mar (TSM) y clorofila $a$ del sensor MODIS-Aqua (1.1 km) y los campos de las corrientes geostróficas durante los periodos de muestreo. Al norte de la malla de muestreo, el patrón de la estructura termohalina mostró intrusiones subsuperficiales de agua subártica modificada, especialmente durante febrero y abril de ambos años. Al sur, en julio y octubre de 2011, se encontraron indicaciones de agua subtropical subsuperficial. Los campos de las corrientes geostróficas en febrero y abril mostraron un flujo superficial hacia el sur a lo largo de la costa, el cual cambió su dirección hacia el Polo Norte en julio y octubre. En primavera, la temperatura derivada de imágenes satelitales mostró anomalías negativas de hasta $4.5^{\circ} \mathrm{C}$ en la zona adyacente a la costa, lo cual corresponde a las surgencias costeras que elevan agua hacia la superficie desde los 60-70 m de profundidad. Con base en los resultados, el área de estudio se puede considerar como el límite sur de la zona de transición entre las aguas subárticas y subtropicales del océano Pacífico nororiental, con una marcada estacionalidad.

Palabras clave: estructura termohalina, plataforma continental, Baja California, corriente de California, océano Pacífico nororiental.

\section{INTRODUCTION}

Oceanographic conditions in the northeastern Pacific Ocean off Baja California (Mexico) are systematically monitored as part of the program known as Investigaciones Mexicanas de la Corriente de California (IMECOCAL, Mexican Investigations of the California Current), a southern extension of the California Cooperative Fisheries Investigations (CalCOFI) program. Synthesis of the long-term data

\section{INTRODUCCIÓN}

Las condiciones oceanográficas del océano Pacífico nororiental frente a Baja California (México) se estudian sistemáticamente mediante el programa Investigaciones Mexicanas de la Corriente de California (IMECOCAL), que es una extensión hacia el sur del programa California Cooperative Fisheries Investigations (CalCOFI). La síntesis de la información a largo plazo obtenida de estos programas 
generated by these programs has resulted in a satisfactory description of the main characteristics of the southern region of the California Current System (CCS) and of its seasonal and interannual variability (e.g., Gómez-Valdés 1983, Lynn and Simpson 1987, Durazo and Baumgartner 2002, Durazo et al. 2010); however, the hydrophysical processes over the continental shelf off the Baja California Peninsula to the south of the Gulf of Ulloa have not been well documented. This coastal area, like the continental shelf off the peninsula, lies outside the IMECOCAL sampling domain. This region contains the largest bays (Magdalena and Almejas) of the Pacific coast of Mexico, known for their high primary productivity (Cervantes-Duarte et al. 2013). The high seasonal and interannual variability of the hydrophysical processes in this area are determined by a weakening of the dominant northwesterly winds along the coast and a moving away from the shelf of the main flow of the California Current (CC) in summer and autumn (Lynn and Simpson 1987).

Analysis of the thermohaline structure along the southernmost IMECOCAL transect lines and the few studies conducted to the south of the Gulf of Ulloa show the frequent occurrence in the upper $100 \mathrm{~m}$ layer of relatively cold, lowsalinity water from the north associated with the CC flow (Durazo et al. 2005). Castro-Valdez et al. (2012) consider that the mean salinity distribution at $50 \mathrm{~m}$ depth, marked by a salinity minimum of 33.6, is associated with the nucleus of the CC and extends to the southern tip of the Baja California Peninsula. Southerly instrusions of warmer, more saline subtropical water have been observed over the continental shelf and slope in summer and autumn, possibly associated with the presence of a poleward countercurrent especially during El Niño years (Durazo and Baumgartner 2002). Durazo (2009) reported the occurrence of large-scale cyclonic circulation off the southern part of the peninsula that can transport subtropical water towards the north over the continental slope and on occasion over the shelf. Hence, both subarctic and tropical waters can be observed in the area during the year. The pattern of currents is characterized by the occurrence of mesoscale (often cyclonic) eddies (Kurczyn et al. 2012).

Upwelling is one of the main hydrophysical processes affecting the study area (Zaitsev et al. 2007). The intensity and extent of upwelling depend mainly on the characteristics of the wind field (Bakun and Nelson 1977), water column stratification, coastline orientation, and regional topography (Figueroa and Moffat 2000). Surface filaments of cold water are frequently observed throughout the CC (Strub et al. 1991). In upwelling zones, filaments and other similar spatial structures are associated with the topography of the continental shelf and coastline irregularities (Castelao and Barth 2006).

The hydrodynamic conditions of the CCS in 2011 developed in response to the dissipation of the 2010 La Niña event in spring and summer, and the reappearance of cold La Niña conditions in autumn and winter 2011; the transition towards permite describir satisfactoriamente las características principales de la región sureña del Sistema de la Corriente de California (SCC) y su variabilidad estacional e interanual (e.g., Gómez-Valdés 1983, Lynn y Simpson 1987, Durazo y Baumgartner 2002, Durazo et al. 2010). Sin embargo, los procesos hidrofísicos sobre la plataforma continental del Pacífico frente a la península de Baja California al sur del golfo de Ulloa no están bien documentados. Esta área costera se encuentra fuera del dominio de estudio del programa IMECOCAL, que tampoco incluye la plataforma continental de la península. En esta región se encuentran localizadas las bahías más grandes de la costa mexicana en el Pacífico (Magdalena y Almejas), reconocidas por su gran productividad primaria (Cervantes-Duarte et al. 2013). La alta variabilidad estacional e interanual de los procesos hidrofísicos en el área se determinan por el debilitamiento de los vientos dominantes del noroeste a lo largo de la costa y un alejamiento de la plataforma del flujo principal de la corriente de California (CC) en verano y otoño (Lynn y Simpson 1987).

Los análisis de la estructura termohalina en los transectos sureños del programa IMECOCAL y los pocos estudios realizados al sur del golfo de Ulloa frecuentemente demuestran la presencia de aguas relativamente frías y poco saladas del norte en la capa superficial de $100 \mathrm{~m}$ de profundidad, asociadas al flujo de la CC (Durazo et al. 2005). Castro-Valdez et al. (2012) consideran que la distribución de la salinidad promedio a $50 \mathrm{~m}$ de profundidad, marcada por un mínimo salino de 33.6, está asociada al núcleo de la CC y se extiende hasta el extremo sur de la península de Baja California. En verano y otoño, sobre el talud y la plataforma continental, se han registrado intrusiones desde el sur de aguas cálidas y más saladas de origen subtropical, que podrían asociarse a la presencia de una contracorriente hacia el polo especialmente en los años de El Niño (Durazo y Baumgartner 2002). Durazo (2009) registró la presencia de una circulación ciclónica de gran escala frente a la parte sur de la península de Baja California que puede transportar aguas subtropicales hacia el norte sobre el talud continental y en ocasiones sobre la plataforma. Por tanto, durante el año se puede observar tanto agua subártica como subtropical en el área. El patrón de corrientes se caracteriza por la aparición recurrente de remolinos de mesoescala, a menudo ciclónicos (Kurczyn et al. 2012).

Uno de los principales procesos hidrofísicos que afecta la zona de estudio es la surgencia costera (Zaitsev et al. 2007). La intensidad y extensión espacial de las surgencias dependen principalmente de las características del campo de viento (Bakun y Nelson 1977), la estratificación de la columna del agua, la orientación de la línea de costa y la topografía regional (Figueroa y Moffat 2000). Frecuentemente se observan filamentos superficiales de agua fría a lo largo de la CC (Strub et al. 1991). En las zonas de surgencia, los filamentos y otras estructuras espaciales similares se relacionan con la topografía de la plataforma continental y con irregularidades en la línea de costa (Castelao y Barth 2006). 
neutral conditions occurred in spring 2012, as indicated by the Multivariate ENSO Index (MEI) and Pacific Decadal Oscillation (PDO) that show average climatological values for that period. The hydrophysical conditions, including coastal upwelling activity in the southern region of the CCS, show a relatively slight response to atmospheric effects relative to the climatological averages (Bjorkstedt et al. 2011, 2012).

This paper aims to analyze the oceanographic conditions over the continental shelf and slope off the MagdalenaAlmejas Bay (MAB) lagoon system on the west coast of the Baja California Peninsula during 2011-2012, to define whether the subarctic water transported by the CC from the north and the subtropical water from the south can reach (in predominant form) these latitudes $\left(>24^{\circ} \mathrm{N}\right)$, and to evaluate coastal upwelling intensity and patterns.

\section{MATERIALS AND METHODS}

Six oceanographic cruises were conducted on board CICESE's R/V Francisco de Ulloa off the MAB lagoon system (fig. 1) during 9-13 February 2011 (hereinafter Feb11), 13-16 April 2011 (Apr11), 4-8 July 2011 (Jul11), 25-29 October 2011 (Oct11), 16-18 February 2012 (Feb12), and 18-21 April 2012 (Apr12). The surveys were performed over a predetermined grid of 68 stations separated by a distance of $\sim 5$ nautical miles (fig. 1c). Maximum depth at the stations farthest from the coast exceeded $1000 \mathrm{~m}$. At each station, a conductivity, temperature, and pressure sensor (SeaBird SBE-9 CTD) was lowered to the bottom or to $500 \mathrm{~m}$ when the depth was greater. The water mass classification used for the temperature and salinity analyses is shown in table 1 (Durazo and Baumgartner 2002).

To complement the spatial and temporal information, we analyzed multi-platform wind data (10 $\mathrm{m}$ above the surface) reported by NOAA's National Climatic Data Center (www.ncdc.noaa.gov/oa/rsad/air-sea/seawinds.html) and the Coastal Upwelling Index (CUI) provided by the Pacific Fisheries Environmental Laboratory (www.pfel.noaa.gov). We also analyzed MODIS-Aqua sea surface temperature and chlorophyll $a$ data (1.1 km resolution) for 2011 and 2012 (http://oceandata.sci.gsfc.nasa.gov/MODISA/), and used geostrophic current fields corresponding to a period of 10 days during each cruise, with $500 \mathrm{db}$ as a reference level. The latter were calculated using sea level anomaly data from NOAA's Atlantic Ocean Marine Laboratory website (www. aoml.noaa.gov/phod/dataphod/work/trinanes/INTERFACE) that displays TOPEX, ERS-2, and GFO altimeter data (spatial resolution of $0.2^{\circ}$ ) and climatological mean dynamic heights estimated based on Levitus climatology for $1000 \mathrm{db}$.

\section{RESUlTS}

Wind conditions in the region during the surveys are shown in figure 2. A comparison of the Feb11 and Feb12 and
El desarrollo del estado hidrodinámico del SCC en 2011 inició con una respuesta a la disipación de La Niña 2010 durante primavera y verano, luego ocurrió un resurgimiento de condiciones frías de La Niña durante otoño e invierno en 2011 y finalmente hubo una transición a condiciones neutrales durante la primavera de 2012, como lo indican el Índice Multivariado de ENSO (MEI, por sus siglas en inglés) y la Oscilación Decenal del Pacífico (PDO), cuyos valores fueron cercanos a los valores climatológicos promedio en esta época. Las condiciones hidrofísicas, incluyendo la actividad de las surgencias costeras en la región sur del SCC, mostraron una respuesta relativamente leve a los efectos atmosféricos en relación con los promedios climatológicos (Bjorkstedt et al. 2011, 2012).

Los objetivos de este trabajo son analizar las condiciones oceanográficas sobre la plataforma y el talud continental frente al complejo lagunar de bahía Magdalena-Almejas (BMA) en la costa occidental de Baja California durante 2011-2012, definir si el agua subártica transportada por la CC (desde el norte) y el agua subtropical (desde el sur) pueden alcanzar en forma predominante estas latitudes $\left(>24^{\circ} \mathrm{N}\right)$, y evaluar la intensidad y patrones de las surgencias costeras.

\section{MATERIALES Y MÉTODOS}

Se llevaron a cabo seis cruceros oceanográficos a bordo del B/O Francisco de Ulloa del CICESE frente al complejo lagunar BMA (fig. 1) durante los periodos 9-13 de febrero de 2011 (en lo sucesivo Feb11), 13-16 de abril de 2011 (Abr11), 4-8 de julio de 2011 (Jul11), 25-29 de octubre de 2011 (Oct11), 16-18 de febrero de 2012 (Feb12) y 18-21 de abril de 2012 (Abr12). Los muestreos se planearon para recorrer una red predeterminada de 68 estaciones separadas por una distancia de $\sim 5$ millas náuticas (fig. 1c). La profundidad máxima de las estaciones más alejadas de la costa excedió los $1000 \mathrm{~m}$. En cada estación, se realizaron lances con una sonda de conductividad, temperatura y presión (CTD, modelo SBE-9 de SeaBird) hasta el fondo o hasta $500 \mathrm{~m}$ cuando la profundidad fue mayor. La clasificación de las masas de agua utilizada en el análisis de temperatura y salinidad se muestra en la tabla 1 (Durazo y Baumgartner 2002).

Para completar la información espacial y temporal, se estudiaron los datos de viento multiplataforma (a $10 \mathrm{~m}$ sobre la superficie) documentados por el National Climatic Data Center de la NOAA (www.ncdc.noaa.gov/oa/rsad/air-sea/ seawinds.html) y el índice de surgencia costera (ISC) obtenido del Pacific Fisheries Environmental Laboratory (www.pfel.noaa.gov). También se analizaron datos de temperatura superficial del mar y clorofila $a$ del sensor MODISAqua (resolución de 1.1 km) para 2011 y 2012 (http://oceandata.sci.gsfc.nasa.gov/MODISA/). Se usaron los campos de las corrientes geostróficas correspondientes a un periodo de 10 días durante cada crucero, con un nivel de referencia de $500 \mathrm{db}$. Estas corrientes se calcularon a partir de los datos de anomalías del nivel del mar de la página del Atlantic Ocean 

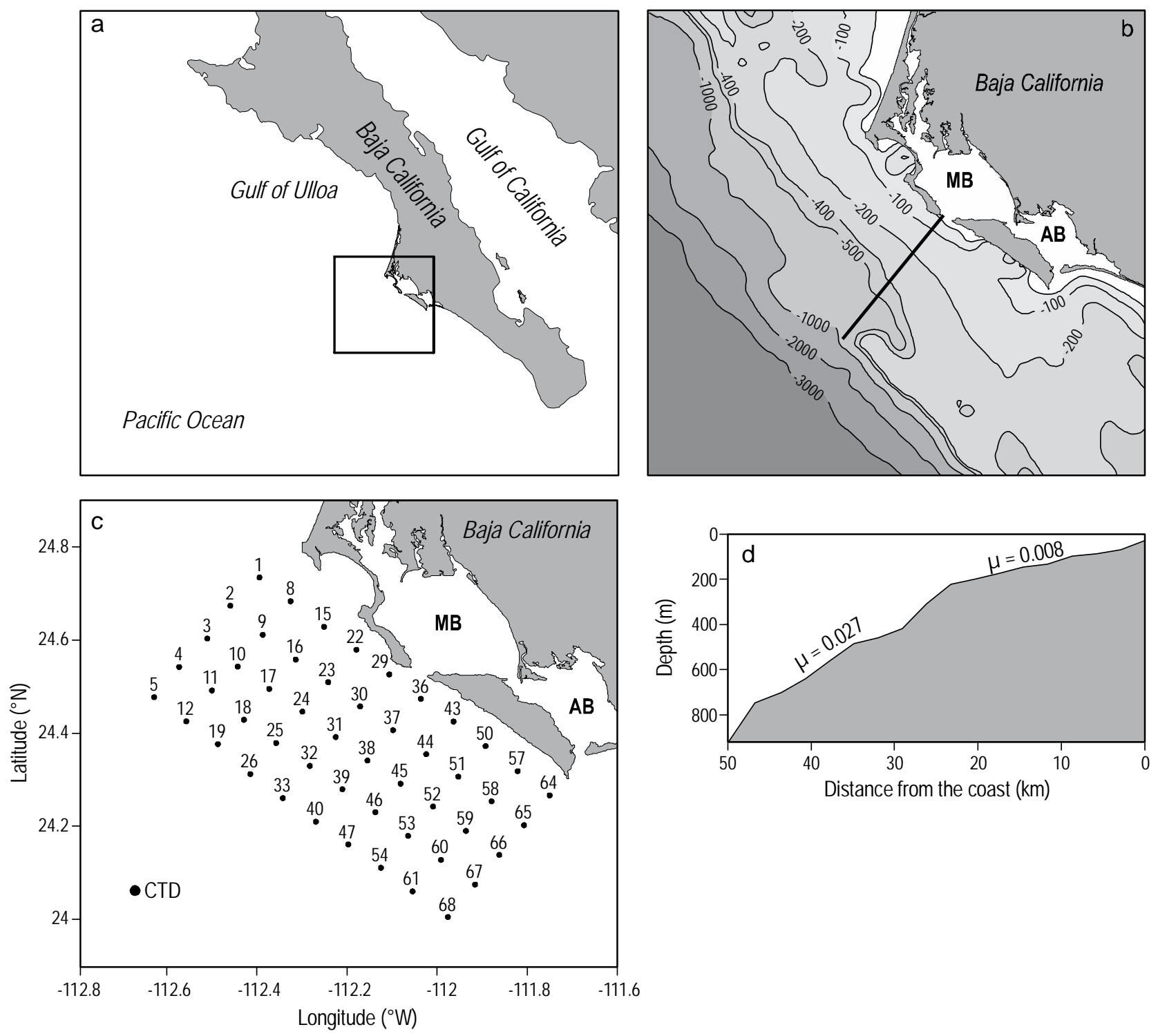

Figure 1. (a) Map of the region (Mexico), (b) bottom topography, (c) hydrographic and hydrochemical sampling grid, and (d) bottom slope $(\mu)$ over a transect marked in (b). The square in (a) indicates the study area off Magdalena Bay (MB) and Almejas Bay (AB).

Figura 1. (a) Mapa de la región (México), (b) topografía del fondo, (c) malla de muestreos hidrográficos e hidroquímicos y (d) pendiente ( $\mu$ ) del fondo a lo largo de un transecto marcado en (b). El cuadro en (a) indica la zona de estudio frente a bahía Magdalena (MB) y bahía Almejas (AB).

the Apr11 and Apr12 mean monthly wind fields revealed no major differences in either magnitude or direction, so only the 2011 fields are shown (fig. 2a, b). In February, wind magnitudes were lower than in April and the prevailing wind direction was from the north-northwest (fig. 2c). In April, the prevailing wind direction was from the northwest and tended to be parallel to the coast, thus favoring coastal upwelling (fig. 2d).

Figure 2c-h shows the daily mean wind time series in the center of the sampling grid (square in fig. 2a, b) and the CUI time series at latitude $24^{\circ} \mathrm{N}$. Though this area is located more than $80 \mathrm{~km}$ from the coast, certain coherence is observed
Marine Laboratory de la NOAA (www.aoml.noaa.gov/phod/ dataphod/work/trinanes/INTERFACE), que integra información de los altímetros satelitales TOPEX, ERS-2 y GFO (resolución espacial de $0.2^{\circ}$ ) y de alturas dinámicas medias climatológicas calculadas con base en la climatología de Levitus para $1000 \mathrm{db}$.

\section{REsultados}

Las condiciones del viento en la región durante los periodos de estudio se muestran en la figura 2. Al comparar Feb11 con Feb12 y Abr11 con Abr12, se observó que los 
Table 1. Classification of water masses (taken from Durazo and Baumgartner 2002).

Tabla 1. Clasificación de masas de agua (tomada de Durazo y Baumgartner 2002).

\begin{tabular}{lcc}
\hline Water mass & $\begin{array}{c}\text { Temperature } \\
\left({ }^{\circ} \mathrm{C}\right)\end{array}$ & Salinity \\
\hline Subarctic Water (SAW) & $8-21$ & $33.0-34.0$ \\
Subtropical Surface Water (SSW) & $20-27$ & $34.4-35.0$ \\
Equatorial Subsurface Water (ESW) & $8-15$ & $34.3-35.0$ \\
\hline
\end{tabular}

between the wind and CUI. Wind magnitude was slightly higher in Apr11 than in Feb11; however, because the directions were favorable for upwelling, CUI values higher than $100 \mathrm{~m}^{3} \mathrm{~s}^{-1}$ were recorded on 16 days in Apr11 but only on 2 days in Feb11 (fig. 2c, d). A similar situation occurred in 2012, when 18 days in April but only one in February had CUI values higher than $100 \mathrm{~m}^{3} \mathrm{~s}^{-1}$, values even exceeding $250 \mathrm{~m}^{3} \mathrm{~s}^{-1}$ in April (fig. 2g, h), because of the upwellingfavorable wind conditions. The highest CUI values ranged from 85 to $140 \mathrm{~m}^{3} \mathrm{~s}^{-1}$ in Feb11 and from 80 to $100 \mathrm{~m}^{3} \mathrm{~s}^{-1}$ in Feb12 (fig. 2c, g). During Jul11, the intensity of the wind weakened and the corresponding CUI values were lower (fig. 2e); the negative CUI values (23 and 24 July) may be explained by the passage of Hurricane Dora. The upwelling events were less intense in Oct11 (fig. 2f) than in Apr11; seven values exceeded $100 \mathrm{~m}^{3} \mathrm{~s}^{-1}$ (fig. 2d), indicating a second, though less intense, upwelling season.

The vertical profiles of the thermohaline variables for all the stations on the two transect lines farthest from the coast (stations 5-68 and 4-67, fig. 1c) were averaged to show the variation in regional stratification in relation to the nucleus of the CC flow, far from the influence of the upwelling zone. The water column was less stratified in the winter and spring months of both years, with temperatures of $18^{\circ} \mathrm{C}$ at the surface and decreasing to $\sim 12{ }^{\circ} \mathrm{C}$ at $200 \mathrm{~m}$ depth (fig. 3). Maximum stratification was observed in Oct11, with temperatures of 27 and $12{ }^{\circ} \mathrm{C}$ at the surface and $200 \mathrm{~m}$ depth, respectively. A well-mixed layer was noticeable at the surface in Oct11 and reached $40 \mathrm{~m}$ in Feb12. An intermediate layer of low salinity ( 33.8) was observed between 50 and $80 \mathrm{~m}$ depth in all the surveys. In Feb11, Apr11, and Apr12, this low salinity layer was observed from the surface to $80 \mathrm{~m}$ depth due to the influence of the CC in this area.

The distribution of temperature in the upper $10 \mathrm{~m}$ layer is shown in figure 4 . In winter and spring, offshore surface temperatures were close to $18{ }^{\circ} \mathrm{C}$ and an intense thermal front developed parallel to the shore. The presence of cold (min. $14^{\circ} \mathrm{C}$, fig. 4b) and saline (max. 34.6, fig. 5b) water near the coast in February and April of both years is due to the persistence of coastal upwelling in the study area. The thermal fronts in Feb11 and Feb12 (fig. 4a, e) were less intense than in Apr11 and Apr12 (fig. 4b, f). In contrast, in Jul11, the surface temperature distribution showed less variation; campos de viento promedio mensuales no presentan mayores diferencias tanto en magnitud como en dirección, y por tal razón sólo se muestran los campos de 2011 (fig. 2a, b). En febrero, las magnitudes del viento fueron menores que en abril y la dirección predominante del viento fue del nornoroeste (fig. 2c). En abril, la dirección predominante del viento fue del noroeste con tendencia a ser paralela a la línea de costa, favoreciendo así el aumento de la surgencia costera (fig. 2d).

La figura 2c-h muestra las series de tiempo del viento (promedio diario) en el centro de la malla de muestreo (cuadro marcado en fig. 2a, b) y las del ISC en la latitud $24^{\circ} \mathrm{N}$. Aunque estos puntos están situados a una distancia mayor que $80 \mathrm{~km}$ de la costa, se observó cierta coherencia entre el viento y el ISC. La magnitud del viento en Abr11 fue ligeramente mayor que en Feb11. Sin embargo, debido a las direcciones favorables a la surgencia, se observaron 16 días con ISC mayores que $100 \mathrm{~m}^{3} \mathrm{~s}^{-1}$ en Abr11 y solamente 2 días en Feb11 (fig. 2c, d). Una situación similar ocurrió en 2012, cuando se presentaron 18 días de abril y sólo un día en febrero con valores del ISC mayores que $100 \mathrm{~m}^{3} \mathrm{~s}^{-1}$, incluso alcanzando valores mayores que $250 \mathrm{~m}^{3} \mathrm{~s}^{-1}$ en abril, debido a las direcciones favorables a la surgencia (fig. $2 \mathrm{~g}, \mathrm{~h}$ ). Los valores más altos del ISC variaron de 85 a $140 \mathrm{~m}^{3} \mathrm{~s}^{-1}$ en Feb11 y de 80 a $100 \mathrm{~m}^{3} \mathrm{~s}^{-1}$ en Feb12 (fig. 2c, g). Durante Jul11, se observó un debilitamiento en la intensidad del viento y los valores de los ISC correspondientes fueron menores (fig. 2e); los valores negativos del ISC (23 y 24 de julio) podrían explicarse por la influencia del paso del huracán Dora. Los eventos de surgencia fueron menos intensos en Oct11 (fig. 2f) que en Apr11; se observaron siete valores mayores que $100 \mathrm{~m}^{3} \mathrm{~s}^{-1}$ en Apr11 (fig. 2d), lo cual indicó una segunda temporada de surgencias, aunque de menor intensidad.

Se promediaron los perfiles verticales de las variables termohalinas en todas las estaciones de las dos líneas más alejadas de la costa (estaciones 5-68 y 4-67, fig. 1c) para mostrar la variación de la estratificación de la región con relación al núcleo del flujo de la CC, lejos de la influencia de la zona de surgencias. La columna de agua estuvo menos estratificada en los meses de invierno y primavera de ambos años (fig. 3). En ambos meses, la temperatura fue de $18^{\circ} \mathrm{C}$ en la superficie y disminuyó a $\sim 12{ }^{\circ} \mathrm{C}$ a $200 \mathrm{~m}$ de profundidad. La estratificación máxima se observó en Oct11, con temperaturas de 27 y $12{ }^{\circ} \mathrm{C}$ en la superficie y a $200 \mathrm{~m}$ de profundidad, respectivamente. Se observó una capa bien mezclada en la superficie en Oct11 que aumentó a 40 m en Feb12. También se observó una capa intermedia de baja salinidad (hasta de 33.8) entre 50 y $80 \mathrm{~m}$ de profundidad en todos los cruceros. En Feb11, Abr11 y Abr12, esta capa de baja salinidad se localizó desde la superficie hasta los $80 \mathrm{~m}$ de profundidad debido a la influencia de la CC en esta zona.

La distribución de temperatura en la capa de $10 \mathrm{~m}$ de profundidad se muestra en la figura 4. En invierno y primavera, afuera de la costa, se observó agua superficial con valores cercanos a $18^{\circ} \mathrm{C}$ y se desarrolló un intenso frente térmico 

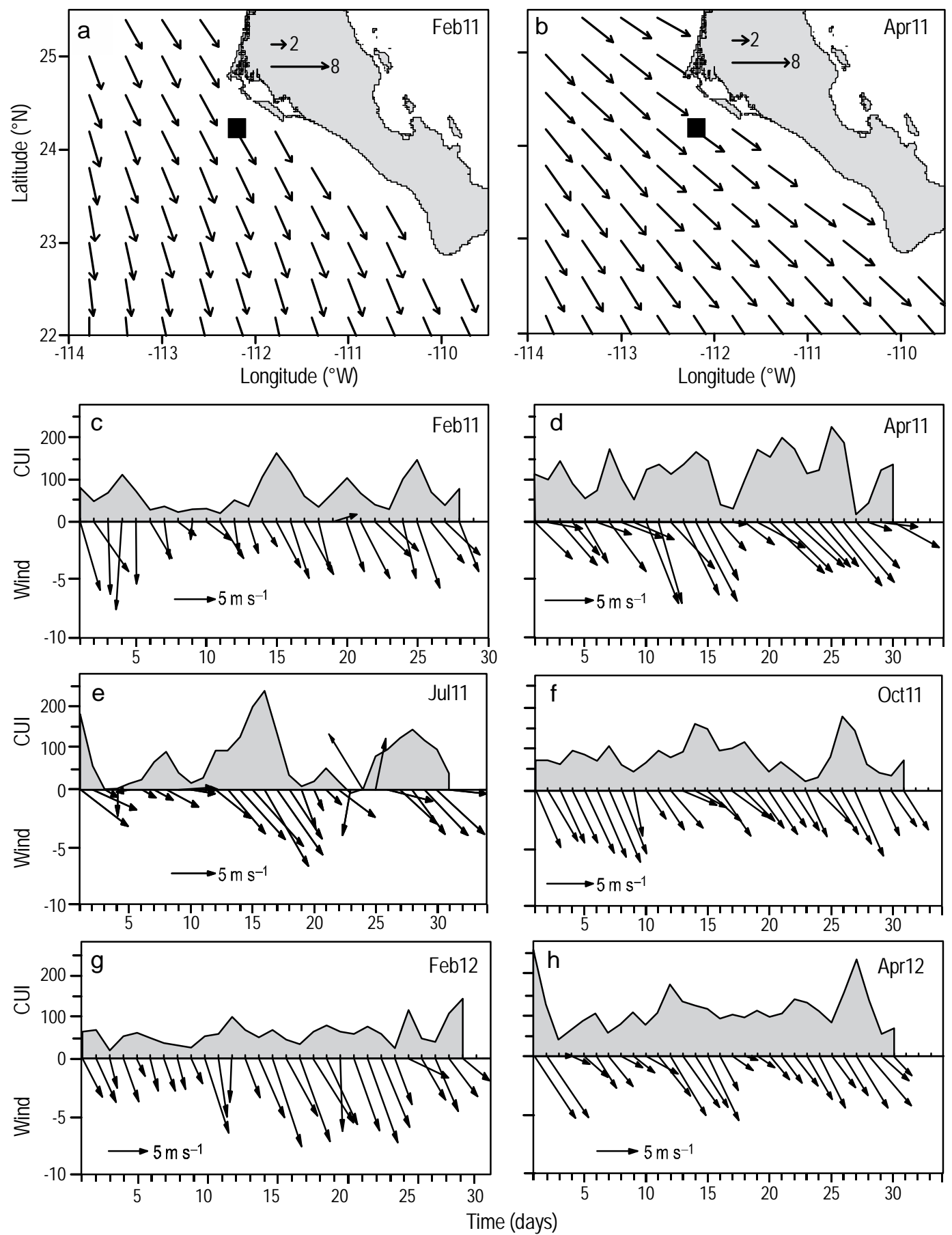

Figure 2. Wind fields in (a) February 2011 and (b) April 2011. (c-h) Coastal Upwelling Index (CUI, $\mathrm{m}^{3} \mathrm{~s}^{-1}$ per $100 \mathrm{~m}$ of coastline) and mean diurnal wind vectors at the square marked in (a) and (b) for February 2011 (c), April 2011 (d), July 2011 (e), October 2011 (f), February 2012 (g), and April 2012 (h).

Figura 2. Campos de viento en (a) febrero y (b) abril de 2011. (c-h) Índice de Surgencia Costera (CUI, $\mathrm{m}^{3} \mathrm{~s}^{-1}$ por $100 \mathrm{~m}$ de línea de costa) y vectores diurnos promedio del viento en el cuadro marcado en (a) y (b) para febrero de 2011 (c), abril de 2011 (d), julio de 2011 (e), octubre de 2011 (f), febrero de 2012 (g) y abril de 2012 (h). 


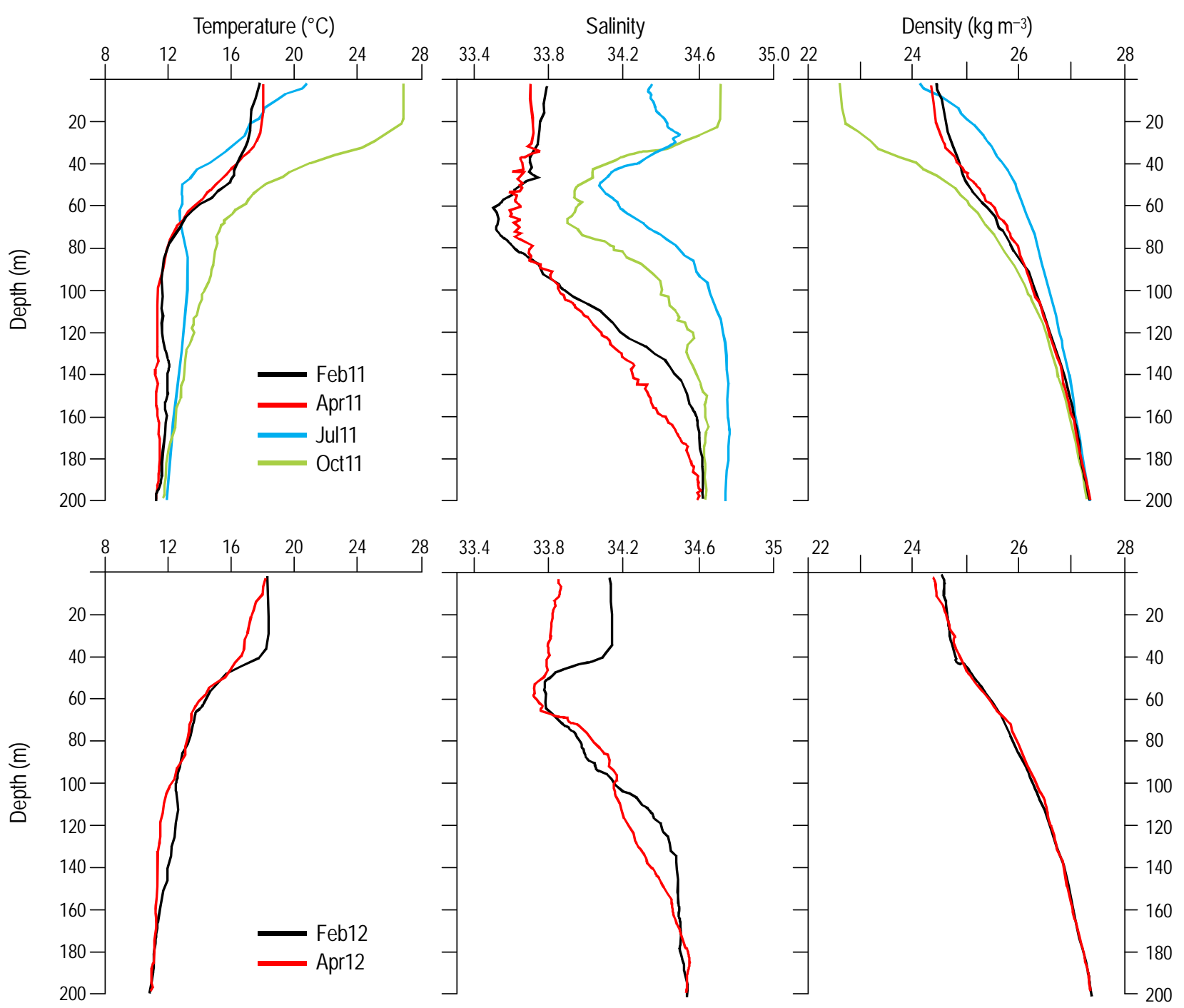

Figure 3. Average profiles of the thermohaline variables along the two most offshore transect lines (stations 5-68 and 4-67 in fig. 1c) for all cruises.

Figura 3. Perfiles promedio de las variables termohalinas en las dos líneas más alejadas de la costa (estaciones 5-68 y 4-67 en fig. 1c) para todos los cruceros.

temperatures ranged from 17.5 to $19^{\circ} \mathrm{C}$ and were slightly warmer in the southern part of the study area, reaching $20.5^{\circ} \mathrm{C}$ near the coast (fig. 4c). In Oct11, a patch of cooler $\left(24.0^{\circ} \mathrm{C}\right)$, less saline (34.4) water was observed in the northwestern part of the study area (figs. $4 \mathrm{~d}, 5 \mathrm{~d}$ ). Only in this month was the instrusion of warm water observed in the center of the sampling grid (with temperature equal to or higher than $27^{\circ} \mathrm{C}$ ), apparently of tropical origin as indicated by its salinity range (see fig. $5 \mathrm{~d}$ ).

The distribution of salinity in the upper $10 \mathrm{~m}$ layer in winter and spring showed a similar pattern to that of surface temperature, with a strong ocean-coast gradient near the coast (fig. 5). This gradient was stronger in the two April cruises and in the southeastern part of the study area. Except in Feb12, in winter and spring the most offshore stations showed a nearly uniform salinity field, with little variation in paralelo a la costa. La presencia de agua fría (de hasta $14{ }^{\circ} \mathrm{C}$, fig. 4b) y salina (hasta de 34.6, fig. 5b) cerca de la costa durante febrero y abril de ambos años se debe a la persistencia de las surgencias costeras en el área de estudio. Los frentes térmicos en Feb11 y Feb12 (fig. 4a, e) fueron menos intensos en comparación con Abr11 y Abr12 (fig. 4b, f). En contraste, en Jul11, la distribución de temperatura superficial mostró variaciones menores; la temperatura varió entre 17.5 y $19{ }^{\circ} \mathrm{C}$ y fue ligeramente más cálida en la parte sur del área de estudio, donde alcanzó $20.5^{\circ} \mathrm{C}$ cerca de la costa (fig. 4c). En Oct11, se observó una parcela de agua con menor temperatura $\left(24.0^{\circ} \mathrm{C}\right)$ y salinidad (34.4) en la porción noroeste de la malla de muestreo (figs. 4d, 5d). Sólo en este mes se observó la intrusión de agua cálida en el centro de la malla (con temperatura igual o superior a $27^{\circ} \mathrm{C}$ ), al parecer de origen tropical por su intervalo de salinidad (ver fig. $5 d$ ). 

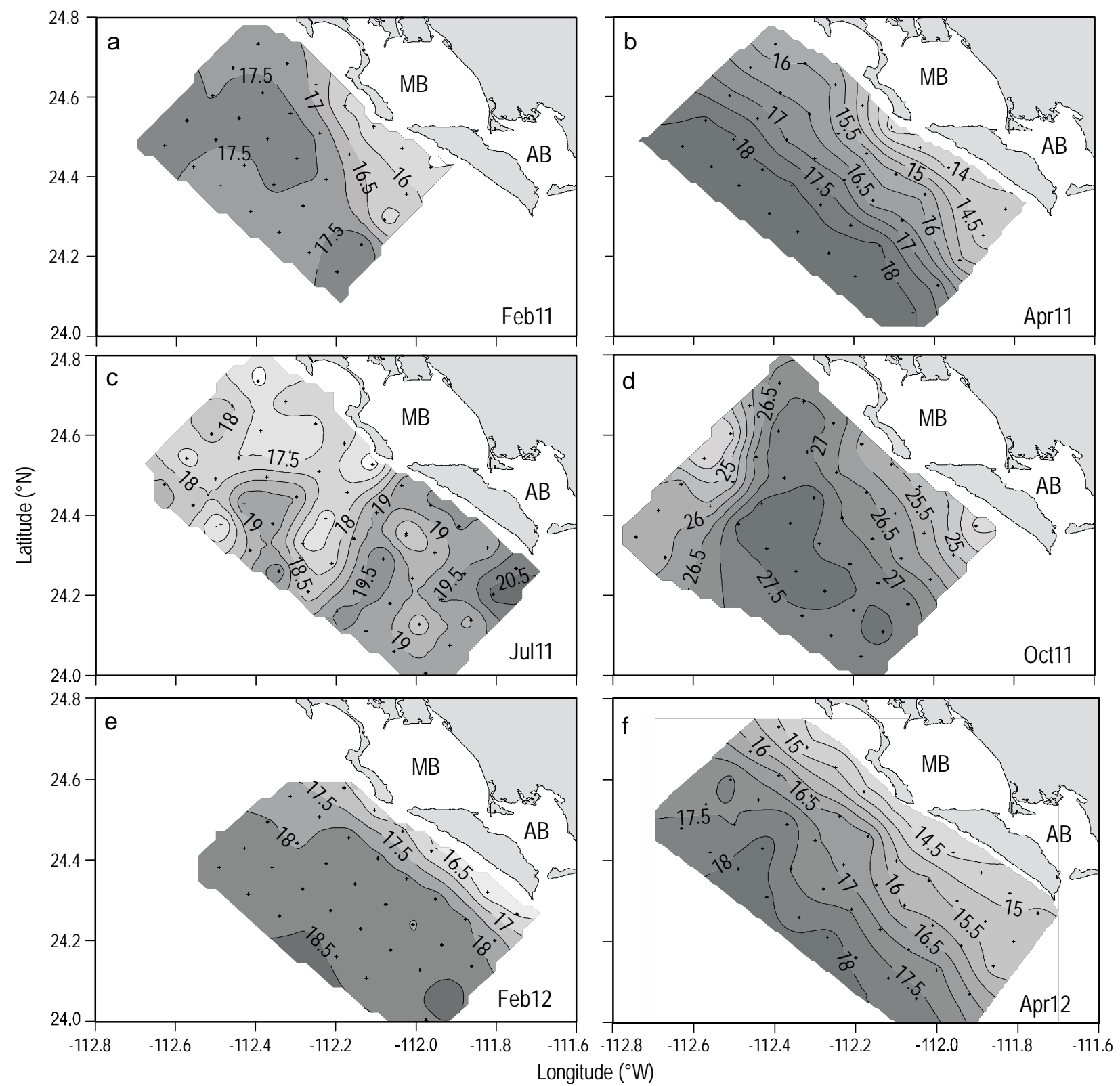

Figure 4. Surface temperature $\left({ }^{\circ} \mathrm{C}\right)$ distribution in the upper $10 \mathrm{~m}$ layer for all cruises. MB, Magdalena Bay; AB, Almejas Bay.

Figura 4. Distribución de temperatura $\left({ }^{\circ} \mathrm{C}\right)$ en la capa superficial de 10 m para todos los cruceros. MB, bahía Magdalena; AB, bahía Almejas.

the range of 33.7 to 34.0 , indicating the effect in the region of modified CC water (fig. 5a, b, f). In Feb12, the coastal gradient and influence of the CC were weaker and salinity values were higher, between 34.0 and 34.2 (fig. 5e). In Jul11, salinity was lowest (33.8) at the oceanic stations in the northern part of the study area and increased shoreward to 34.7 (fig. 5c). In Oct 11 (fig. 5d), the surface salinity field was almost uniform, values ranging from 34.7 to 34.8 , except in the middle of the northwestern part of the grid where it decreased to 34.6; these values are typical of subtropical surface waters.

At $80 \mathrm{~m}$ depth, the temperature and salinity fronts related to coastal upwelling were not as strong as at $10 \mathrm{~m}$ depth
Las distribuciones de salinidad en la capa de $10 \mathrm{~m}$ de profundidad en invierno y primavera mostraron un patrón similar al de la temperatura superficial, con un gradiente océano-costa muy intenso cerca de la costa (fig. 5). Este gradiente fue más intenso en los dos cruceros de abril y en la parte suroriental del área del estudio. Excepto en Feb12, durante invierno y primavera las estaciones más alejadas de la costa mostraron un campo de salinidad prácticamente uniforme, con poca variación dentro del intervalo de 33.7 a 34.0, mostrando el efecto en la región del agua modificada de la CC (fig. 5a, b, f). En Feb12, el gradiente costero y la influencia de la CC fue más débil y la salinidad alcanzó valores más elevados, entre 34.0 y 34.2 (fig. 5e). En Jul11, la salinidad 

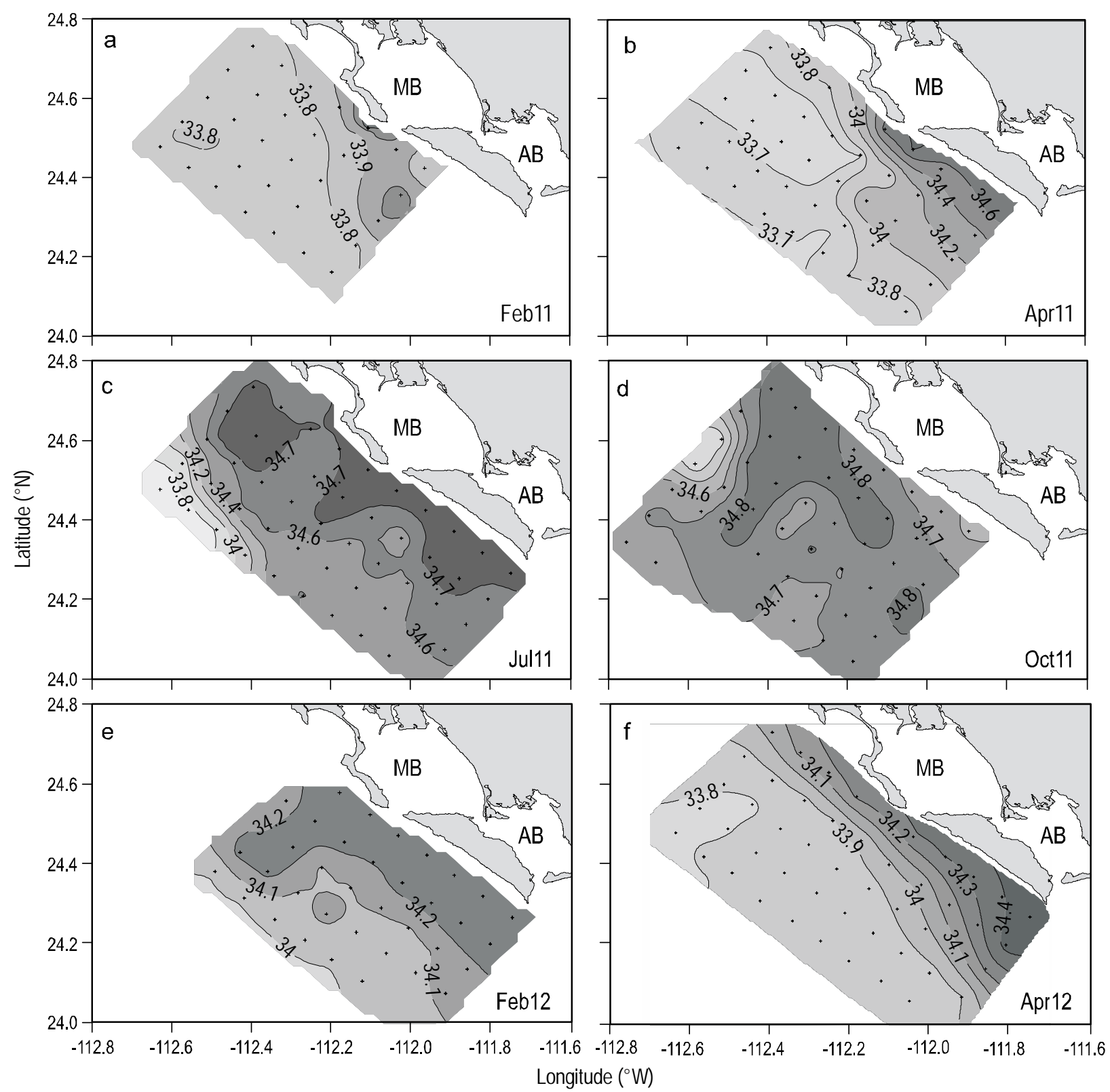

Figure 5. Surface salinity distribution in the upper 10 m layer for all cruises. MB, Magdalena Bay; AB, Almejas Bay.

Figura 5. Distribución de salinidad en la capa superficial de 10 m para todos los cruceros. MB, bahía Magdalena; AB, bahía Almejas.

(figs. 6, 7). In Feb11, subsurface intrusion of warmer water was observed near the coast, especially in the southern part of the study area; temperatures ranged from $14.5^{\circ} \mathrm{C}$ at the nearshore stations to $12{ }^{\circ} \mathrm{C}$ offshore (fig. 6a). In Apr11, Feb12, and Apr12, the temperature field at $80 \mathrm{~m}$ depth was almost homogeneous, with differences of $\sim 0.5^{\circ} \mathrm{C}$ (fig. 6b, e, f). Among these three surveys, the lowest temperature field was observed in Apr11, with values ranging from 11.5 to $12.0^{\circ} \mathrm{C}$, though temperatures of $12.5^{\circ} \mathrm{C}$ were recorded in the southern part of the grid (fig. 6b). The pattern for Jul11 was similar to that of Feb11, except that the ocean-coast gradient was not as marked and water temperatures above $13^{\circ} \mathrm{C}$ were recorded in nearly all the study area (fig. 6c). In Oct11, most of the study superficial mínima de 33.8 se registró en las estaciones más alejadas (norte de la malla de muestreo) y aumentó hacia la costa hasta alcanzar valores de 34.7 (fig. 5c). En Oct11, el campo de salinidad fue casi uniforme y varió sólo entre 34.7 y 34.8, excepto en la región central del noroeste de la malla de muestreo, donde disminuyó a 34.6; estos valores son típicos de las aguas subtropicales superficiales.

A $80 \mathrm{~m}$ de profundidad, los frentes térmicos y de salinidad relacionados con surgencias costeras no fueron tan intensos como a 10 m (figs. 6, 7). En Feb11, se observó a esa profundidad una intrusión de agua con mayor temperatura en las estaciones costeras, especialmente en el sur de la malla de muestreo; la temperatura varió de $14.5^{\circ} \mathrm{C}$ cerca de la costa a 

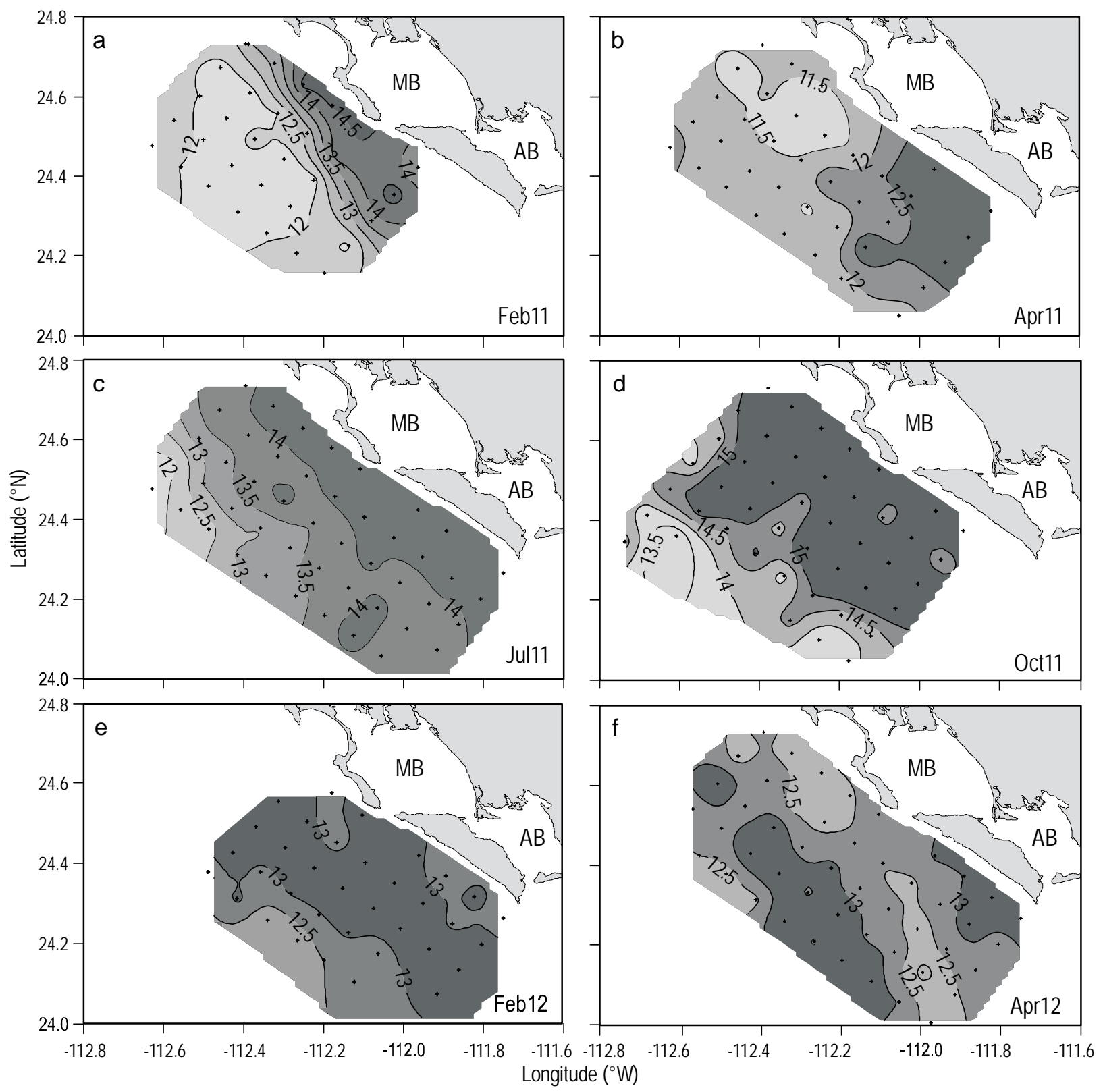

Figure 6. Temperature $\left({ }^{\circ} \mathrm{C}\right)$ distribution at $80 \mathrm{~m}$ depth. $\mathrm{MB}$, Magdalena Bay; $\mathrm{AB}$, Almejas Bay.

Figura 6. Distribución de temperatura $\left({ }^{\circ} \mathrm{C}\right)$ a los $80 \mathrm{~m}$ de profundidad. $\mathrm{MB}$, bahía Magdalena; $\mathrm{AB}$, bahía Almejas.

area was dominated by temperatures of $15^{\circ} \mathrm{C}$; values below $14.0^{\circ} \mathrm{C}$ were recorded only at the most offshore stations (fig. 6d).

Salinity at $80 \mathrm{~m}$ depth also presented coast-ocean fronts in winter and spring. They were more marked in Feb11 (fig. 7a) and Apr11 (fig. 7b) with approximate gradients of 0.50 and 0.35 , respectively, over $10 \mathrm{~km}$. Salinity was 33.7, typical of modified CC water, at the oceanic stations and $\sim 34.4$, characteristic of subtropical water, close to the coast in the southeastern part of the study area. In Jul11, salinity values higher than 34.5 were recorded in most of the study area, except at the northwesternmost stations, where values close
$12{ }^{\circ} \mathrm{C}$ mar adentro (fig. 6a). En Abr11, Feb12 y Abr12, el campo de temperatura a $80 \mathrm{~m}$ de profundidad fue casi homogéneo, con diferencias cercanas a $0.5^{\circ} \mathrm{C}$ (fig. 6b, e, f). Entre estos tres escenarios, el campo de menor temperatura se presentó en Abr11, con valores de 11.5 a $12.0^{\circ} \mathrm{C}$, aunque en la parte sur de la malla de muestreo se observaron temperaturas de $12.5^{\circ} \mathrm{C}$ (fig. 6b). En Jul11 se observó un patrón similar al de Feb11, con la diferencia de que el gradiente océano-costa no fue tan intenso y el agua con temperatura mayor que $13{ }^{\circ} \mathrm{C}$ estuvo distribuida en casi toda el área de estudio (fig. 6c). En Oct11, gran parte del área de estudio estuvo dominada por valores de $15^{\circ} \mathrm{C}$, y solamente en las estaciones más alejadas 

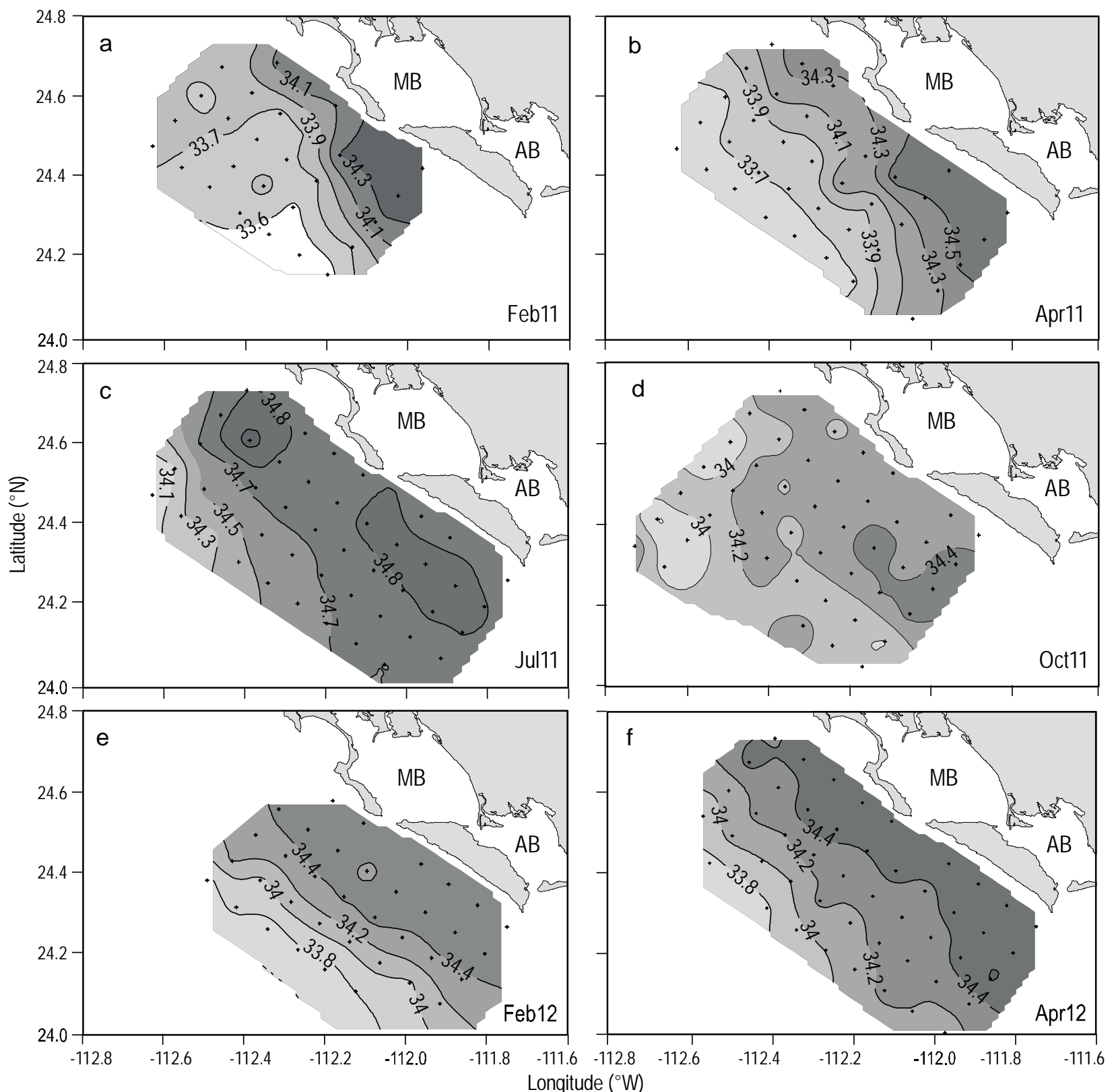

Figure 7. Salinity distribution at $80 \mathrm{~m}$ depth. MB, Magdalena Bay; AB, Almejas Bay.

Figura 7. Distribución de salinidad a los 80 m de profundidad. MB, bahía Magdalena; AB, bahía Almejas.

to 34.1 were found (fig. 7c). In Oct11, salinity ranged from 34.0 at the oceanic stations to 34.4 near the coast (fig. $7 d$ ).

Temperature and salinity distributions in a vertical cross section of a transect line (stations 29-33) initiating at the mouth of Magdalena Bay are shown in figure 8. The Feb11 temperature section shows a rising of the 16 and $17^{\circ} \mathrm{C}$ isotherms between stations 30 and 31 (fig. 8a), forming a weak surface thermal front of $16-17^{\circ} \mathrm{C}$, whereas the 14 and $15^{\circ} \mathrm{C}$ isotherms deepen to $100 \mathrm{~m}$ depth. This is evidence of a process that occurs during and after coastal upwelling. The baroclinic response of the isotherm is the opposite of the rising of the most superficial structure, and it deepens (Gill 1982). de la costa se encontraron temperaturas menores que $14^{\circ} \mathrm{C}$ (fig. 6d).

La salinidad a $80 \mathrm{~m}$ de profundidad también presentó frentes costa-océano en invierno y primavera. Éstos fueron más marcados en Feb11 (fig. 7a) y Abr11 (fig. 7b) con gradientes aproximados de 0.50 y 0.35 , respectivamente, en $10 \mathrm{~km}$; la salinidad fue de 33.7, típica del agua modificada de CC, en las estaciones oceánicas y de $~ 34.4$, típica del agua subtropical, cerca de la costa al suroriente de la malla de muestreo. En Jul11, la mayor parte del área de estudio presentó salinidades superiores a 34.5, y sólo en las estaciones más noroccidentales se encontraron salinidades cercanas a 


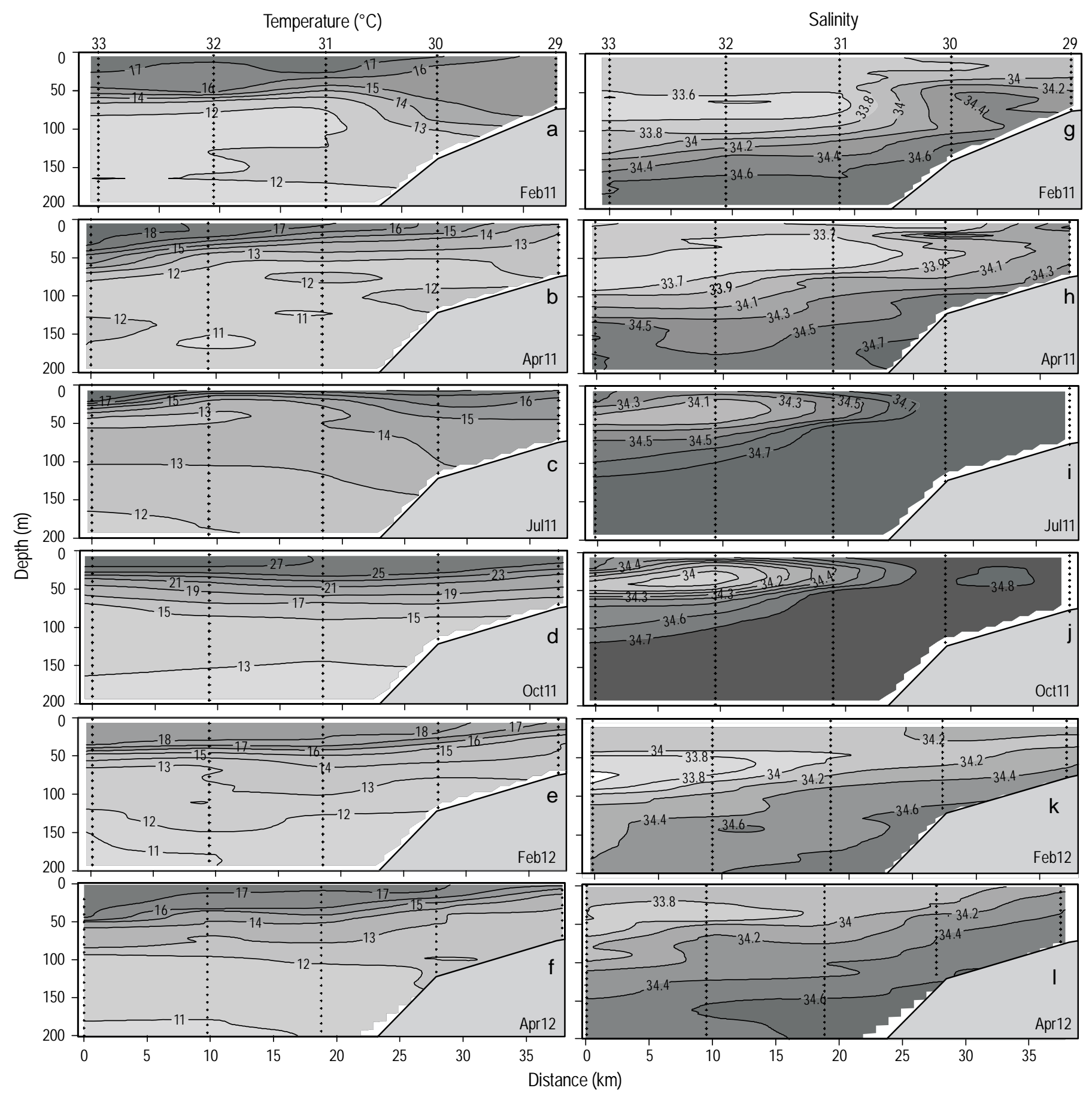

Figure 8. Temperature and salinity distributions in a vertical cross section between stations 29 and 33 (numbers at the top) (fig. 1c) for all cruises.

Figura 8. Distribución de temperatura y salinidad en la sección vertical transversal entre las estaciones 29 y 33 (números en la parte superior) (fig.1c) para todos los cruceros.

Salinity showed a strong front between stations 30 and 31 (33.6-34.4 over $9 \mathrm{~km}$ ) centered at $50 \mathrm{~m}$. Between stations 31 and 33 , at 50 to $80 \mathrm{~m}$ depth, salinity was lower than 33.8 , indicating the presence of CC water.

The February and April sections of both years display many similar features. All show the rising of the isotherms
34.1 (fig. 7c). En Oct11, la salinidad varió de 34.0 en las estaciones oceánicas a 34.4 cerca de la costa (fig. 7d).

En la figura 8 se muestran las secciones transversales de temperatura y salinidad de un transecto (estaciones 29-33) que inicia en la entrada de bahía Magdalena. La sección de Feb11 muestra un levantamiento de las isotermas de $16 \mathrm{y}$ 
and, to a different extent, the baroclinic response of the thermocline, which is consistent with coastal upwelling (fig. 8b, e, f). The upwelling pattern in these periods can also be observed in the salinity sections (fig. 8h, k, l), with values higher than 34.0 near the coast and to more than $80 \mathrm{~m}$ depth. In Apr11, the $14{ }^{\circ} \mathrm{C}$ isotherm shows the maximum excursion observed, rising from $60 \mathrm{~m}$ depth to the surface (fig. 8b). The intrusion of CC water also occurs in Apr11, clearly marked by salinities lower than 33.7 (fig. 8h). Feb12 and Apr12 showed similar patterns, except that low salinity water $(<33.8)$ occupied a shallower layer $(30-50 \mathrm{~m})$ in the latter.

A structure corresponding to a poleward geostrophic flow was observed in Jul11 (fig. 8c). According to the thermal wind law, nearshore warm water is consistent with a geostrophic flow towards the interior of the section (to the north), which in the salinity sections shows a coastal composition that corresponds to subtropical water because of its relatively high temperature and salinity of 34.7 or higher (fig. 8c, i). In Oct11, the salinity structure observed in July reappeared, but then the near-surface temperature was much higher. Moreover, in Oct11, the water column was uniformly stratified (fig. 8d), with surface temperatures of $>25^{\circ} \mathrm{C}$ at nearshore stations and $>27^{\circ} \mathrm{C}$ at oceanic stations. During these months, a reduced salinity range was observed in the upper $100 \mathrm{~m}$ between stations 31 and 33, with a minimum value of $~ 34.0$ between 20 and $50 \mathrm{~m}$ depth (fig. 8i, j). The salinity of shelf waters and at depths greater than $100 \mathrm{~m}$ was almost homogeneous, with values of 34.7 to 34.8 , characteristic of subtropical water.

Figure 9 shows the temperature-salinity diagrams for the sampling periods. In winter and spring of 2011 and 2012, Subarctic Water (SAW) was detected to $100 \mathrm{~m}$ depth, with characteristics typical of water transported by the CC (fig. 9a, b, e, f); this water mass was better represented in 2011 from the surface to $100 \mathrm{~m}$. Below $150 \mathrm{~m}$ depth, the area was dominated by Equatorial Subsurface Water (ESW). In Jul11, SAW (blue color in fig. 9c) was observed only at some offshore stations in the northern part of the study area and in the upper $100 \mathrm{~m}$ layer, indicating the intrusion of water from the north. In Oct11, SAW was observed in a subsurface layer, between 50 and $100 \mathrm{~m}$ depth, at all the northern stations and some central stations. In the southern part (red color in fig. 9c, d), in Jul11 and Oct11 there was no evidence of SAW in the water column. Subtropical Surface Water (SSW) was observed only in Jul11 and Oct11 in the upper $100 \mathrm{~m}$ layer, with greater presence in the latter.

The temperature-salinity diagrams (fig. 9) indicate that the relative salinity minimum, associated with the nucleus of the CC, is found at the $25 \mathrm{~kg} \mathrm{~m}^{-3}$ isopycnal. The density behavior indicates that the water associated with the $25 \mathrm{~kg} \mathrm{~m}^{-3}$ isopycnal (hereinafter $25 \sigma_{\mathrm{t}}$ ) rises from $50 \mathrm{~m}$ depth in Feb12 and Apr12 and from 70 m depth in Apr11 (fig. 10). The Apr11 and Apr12 upwelling indices were similar in magnitude, except that the CUI tended to decrease in 2011 and to $17^{\circ} \mathrm{C}$ entre las estaciones 30 y 31 (fig. 8a), formando un débil frente térmico superficial de $16-17^{\circ} \mathrm{C}$, mientras que las isotermas de 14 y $15{ }^{\circ} \mathrm{C}$ se profundizaron hasta $100 \mathrm{~m}$. Esto es evidencia de un proceso que ocurre durante y después de una surgencia costera. La respuesta baroclínica de la isoterma es opuesta a la elevación de la estructura más superficial y se vuelve más profunda (Gill 1982). Entre las estaciones 30 y 31, la salinidad mostró un frente intenso (33.6-34.4 en 9 km) centrado en $50 \mathrm{~m}$. Entre las estaciones 31 y 33, en la capa de 50 a $80 \mathrm{~m}$, la salinidad fue menor que 33.8, indicando la presencia de agua de la CC.

Las secciones en febrero y abril de ambos años presentan muchas características en común. En todas ellas se observó el levantamiento de las isotermas $\mathrm{y}$, en diferente grado, la respuesta baroclínica de la termoclina, lo cual es consistente con el fenómeno de surgencia costera (fig. 8b, e, f). El patrón de surgencia en estos periodos también se pudo observar en las secciones de salinidad (fig. 8h, k, l), con valores mayores que 34.0 cerca de la costa y a profundidades mayores que $80 \mathrm{~m}$. En Abr11, la isoterma de $14{ }^{\circ} \mathrm{C}$ exhibió la máxima excursión observada, con un ascenso desde $60 \mathrm{~m}$ de profundidad hasta la superficie (fig. 8b). También en Abr11 ocurre la intrusión de agua de la CC, claramente marcada por salinidades menores que 33.7 (fig. 8 h). En Abr12, se observó un patrón similar al de Feb12, con la diferencia de que el agua con baja salinidad (<33.8) ocupó una capa más somera (30-50 m) en Abr12.

En Jul11, se observó la estructura correspondiente a un flujo geostrófico hacia el polo (fig. 8c). Según la regla de viento térmico, el agua cálida cerca de la costa es consistente con un flujo geostrófico hacia adentro de la sección (hacia el norte), el cual en los cortes de salinidad muestra una composición costera que corresponde al agua de origen subtropical por su temperatura relativamente alta y salinidad de 34.7 o mayor (fig. 8c, i). En Oct11, se repitió la estructura de salinidad observada en julio, aunque ahora la temperatura cercana a la superficie fue mucho mayor. Además, en Oct11 la columna de agua se encontró uniformemente estratificada (fig. 8d), con la temperatura superficial mayor que $25^{\circ} \mathrm{C}$ en la costa y mayor que $27^{\circ} \mathrm{C}$ en las estaciones más oceánicas. En estos meses, la salinidad en la capa de $100 \mathrm{~m}$ de profundidad entre las estaciones 31 y 33 presentó un intervalo reducido, con un valor mínimo de $\sim 34.0$ entre 20 y $50 \mathrm{~m}$ (fig. 8i, j). La salinidad en la plataforma continental y en las profundidades mayores que $100 \mathrm{~m}$ fue prácticamente homogénea y alcanzó valores de 34.7 a 34.8, característico del agua subtropical.

La figura 9 muestra los diagramas de temperatura y salinidad para los periodos muestreados. En invierno y primavera de 2011 y 2012, se detectó Agua Subártica (AS) hasta $100 \mathrm{~m}$ de profundidad, con las características típicas del agua transportada por la CC (fig. 9a ,b, e, f); se observó una mayor representación de esta masa de agua en 2011 desde la superficie hasta $100 \mathrm{~m}$. A profundidades mayores que $150 \mathrm{~m}$, el área 

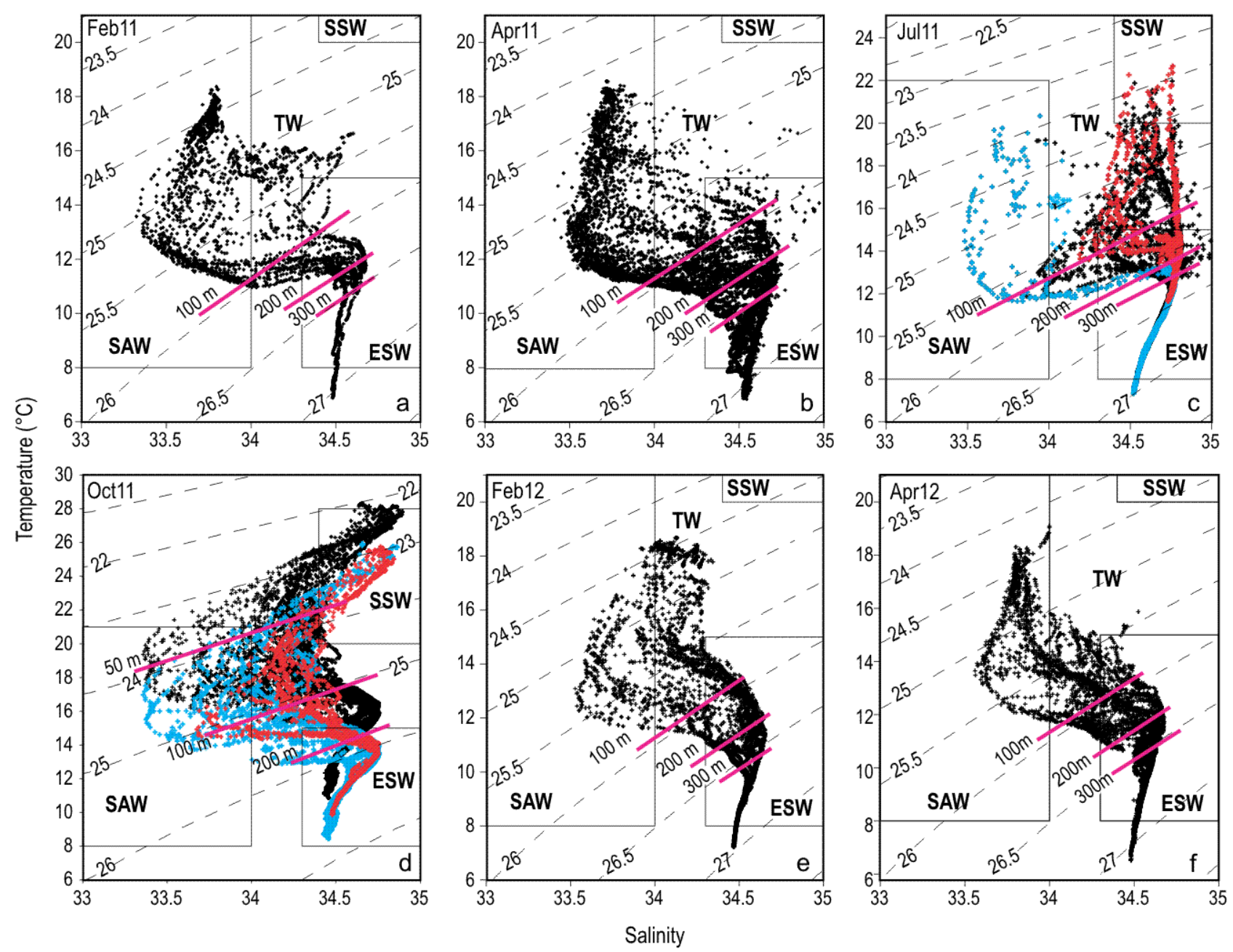

Figure 9. Temperature-salinity diagram for all cruises. SAW, Subarctic Water; SSW, Subtropical Surface Water; ESW, Equatorial Subsurface Water; TW, Transition Water. For a better contrast of the water masses, the data from the two northernmost transect lines are marked in blue and the data from the two southernmost transect lines are marked in red. Pink lines indicate depth.

Figura 9. Diagramas de temperatura y salinidad para todos los cruceros. SAW, Agua Subártica; SSW, Agua Subtropical Superficial; ESW, Agua Ecuatorial Subsuperficial; TW, Agua de Transición. Para un mejor contraste entre las diferentes masas de agua, los datos de las dos líneas del norte de la malla de muestreo están marcados en color azul y los datos de las dos líneas del sur están marcados en rojo. Las líneas rosas indican profundidad.

increase in 2012. Note that the depth of the $25 \sigma_{t}$ isopycnal at the most offshore stations concurs with the depth of the salinity minimum in figure 8.

The topography of the $26 \sigma_{\mathrm{t}}$ isopycnal surface in Apr11 and the temperature and salinity distributions along this surface (fig. 11) were constructed as described by Jerónimo and Gómez-Valdés (2006). This surface was inclined, with minimum depth $(<20 \mathrm{~m})$ near the coast and the deepest part $(>90 \mathrm{~m})$ at the stations farthest from the coast (fig. 11a), indicating a well-defined upwelling pattern. The temperature and salinity distributions on the $26 \sigma_{\mathrm{t}}$ surface show a moderate gradient towards the coast (fig. 11c, d). To the southeast, temperatures above $13.8^{\circ} \mathrm{C}$ were found near the coast, which are relatively high for this depth, compensated by an increase in salinity (> 34.5), similar to the signal of the presence of modified subtropical water. Hence, in summer the northwestern estuvo dominada por Agua Ecuatorial Subsuperficial (AES). En Jul11, el AS (color azul en fig. 9c) fue observada solamente en algunas de las estaciones alejadas de la costa en la parte norte del área de estudio y a profundidades de hasta $100 \mathrm{~m}$, lo cual demuestra la intrusión del agua proveniente del norte. En Oct11, las manifestaciones de AS se observaron en una capa subsuperficial, entre 50 y 100 m profundidad, en todas las estaciones del norte y algunas estaciones centrales. En la parte sur de la malla de muestreo (color rojo en fig. 9c, d), en Jul11 y Oct11 no se encontraron señales de AS en toda la columna. Sólo en estos dos periodos de muestreo se observó Agua Subtropical Superficial (ASS) en los primeros $100 \mathrm{~m}$, con una mayor presencia en octubre.

Los diagramas de temperatura y salinidad (fig. 9) para el área de estudio indican que el mínimo relativo de salinidad, asociado con el núcleo de la CC, está centrado en la isopicna 